\title{
Margaret McCartney: Can doctors fix cold homes?
}

\author{
Margaret McCartney general practitioner, Glasgow
}

Cold homes are bad for health ${ }^{1}$ - and also for the outcome of a society that doesn't care enough about the people at the bottom. The social inequality that poor living conditions reflect is real and leads to people dying younger than they should.

The UK government axed the Warm Homes Healthy People fund in 2012 despite it having been "universally popular" in helping 200000 people a year who needed emergency boiler repairs and hot food. ${ }^{2}$ The National Institute for Health and Care Excellence (NICE) has now made recommendations including the creation of a single point of contact for vulnerable people who need help with housing conditions. This may be useful, but where is the money to help people who have poor living environments but no cash to improve their heating or insulation?

NICE has told GPs that they should "at least once a year, assess the heating needs of people who use their services, whether during a home visit or elsewhere. ${ }^{3}$ But should cold homes be seen as a medical problem rather than a political and social deficit?

During routine work doctors come across all kinds of problems that are not medical. Holistic care is not merely about physical and psychological harms but also environmental ones. Truly preventive medicine concerns social equality, employment, living wages, and clean water, and it extends far into political territory. But GPs cannot take responsibility for the effects of poor housing stock without the power and resources-heating engineers and social workers, for example - to deal with it.

And what of the potential harm in opportunity costs? Our patients are getting older, accumulating more diagnoses, and GPs are dealing with the resultant complexity and polypharmacy, all with fewer hospital beds available. What gets squeezed out to make way for this new work?

In response to concerns about workload, NICE says that improving homes may lead to less work for GPs in the long term. This is nebulous. I remember NICE accepting expert opinion that noted "insufficient capacity within existing primary care resources to meet the increase in demand" when it lowered the recommended threshold for prescribing statins. ${ }^{4}$ But it went ahead anyway.
Improving housing conditions is a moral responsibility of society. For one doctor to discuss heating for three minutes with each patient in a practice of 5000 would take five weeks. As GPs we do not have capes or wear our knickers outside our trousers. To fit this in, then, NICE, what can we stop doing instead?

Follow Margaret on Twitter, @mgtmccartney

Competing interests: I have read and understood the BMJ policy on declaration of interests and declare the following interests: I'm an NHS GP partner, with income partly dependent on Quality and Outcomes Framework points. I'm a part time undergraduate tutor at the University of Glasgow. l've written two books and earn from broadcast and written freelance journalism. I'm an unpaid patron of Healthwatch. I make a monthly donation to Keep Our NHS Public. I'm a member of Medact. I'm occasionally paid for time, travel, and accommodation to give talks or have locum fees paid to allow me to give talks but never for any drug or public relations company. I was elected to the national council of the Royal College of General Practitioners in 2013 and am chair of its standing group on overdiagnosis. I have invested a small amount of money in a social enterprise, Who Made Your Pants?

The BMS s readers can buy Margaret's new book, Living with Dying, for $£ 7.99$ (RRP £11.99) including UK delivery from www.pinterandmartin. com with checkout code BMJ799.

Provenance and peer review: Commissioned; not externally peer reviewed.

Thomson H, Sellstrom E, Petticrew M. The health impacts of housing improvement: a systematic review of intervention studies from 1887-2007. Am J Public Health 2009;99 (suppl 3):S681-92.

2 Public Health England. Cold weather plan for England 2014. 21 October 2014. www.gov. uk/government/publications/cold-weather-plan-for-england-2014

3 National Institute for Health and Care Excellence. Excess deaths and winter mortality and the health risks associated with cold homes. 5 March 2015. www.nice.org.uk/news/article vulnerable-people-living-in-cold-homes-need-greater-support.

4 McCartney M. We lack the tools to help patients decide about statins. BMJ2014;349:g5688 (response: www.bmj.com/content/349/bmj.g5688/rr/765804).

Cite this as: BMJ 2015:350:h1595

๑ B BMJ Publishing Group Ltd 2015 